\title{
Pitfalls Encountered by Bilingual Arab Learners in Translating the Arabic Discourse Marker 'Oumma' into English
}

\author{
Yousef Tahaineh \\ Al-Balqa' Applied University, Amman, Jordan \\ Email: ytahaineh2006@yahoo.com \\ Raid Tafish \\ Al-Balqa' Applied University, Amman, Jordan \\ Email: raidtafish@yahoo.com
}

\begin{abstract}
Modern Standard Arabic (henceforth, MSA) is characterized as syndetic and formulaic language. The current study aimed at investigating the problems that Arab learners of English and translators encounter in translating sentences holding the discourse marker (henceforth, DM) Oumma into English. This may be especially true if these languages are genetically unrelated, as is the case with Arabic and English. Five functions [sequence with span of time, sequence with no span of time, resumption, adversative and consequence] were identified through surveying various kinds of MSA texts. A translation task of 40 Arabic sentences holding the discourse marker $\theta$ umma was performed by a random sample of 55 senior students with similar linguistic, sociocultural and educational backgrounds studying at Al-Balqa' Applied University-Jordan. Findings revealed that the improper translation of functions of the Arabic DM Oumma is still prominent among Arab learners of English even at advanced stages of their learning. The pitfalls were ranked hierarchically in terms of difficulty. Findings of the study were discussed, conclusions had been drawn, implications and future directions were provided at the end.
\end{abstract}

Index Terms - textual functions, bilingual learners, intercultural communication, contrastive linguistics translation, Arabic DM 'Oumma', coordination, EFL learners

\section{INTRODUCTION}

Arab grammarians usually refer to the connectives - according to their different significance - as adawaat-u l-rabț or huruuf al-9atf- i.e. connective particles. Sometimes they are treated under the headings of 9atf nasaq 'conjunction of sequence' and 9atf bayaan 'explicative apposition'. For most of the Arab grammarians, connectives are treated as linking devices, and their function is mainly to coordinate units such as words, phrases, clauses, sentences, etc. In other words, there is a consensus among Arab grammarians that huruuf al-9atf- 'conjunction particles', 'discourse connectives' or 'discourse markers' (henceforth, DMs) are common cohesive devices, or adawaat-u l-rabt 'connectives' that connect one part of discourse with another- are a pervasive feature of MSA syntax (see Al-Hmouz, M.A.2001,p.364). However, in this study, the acronym DMs is used in lieu of connectives or conjunctions. Arabic sentences and clauses within a text are connected and interconnected by means of words or phrases (such as Aumma, 'then') that subordinate, coordinate, and otherwise link them semantically and syntactically (Karin, C.R.2005,p.407). Despite the fact that DMs play an important role in information processing in both modes of communication: speech and writing, analysis of DMs in English has tended to focus on spoken conversation, whereas analysis of DMs in Arabic (Johnstone 1990, Al-Batal 1990, Kammensjo1993) has focused particularly on the structure of written discourse, because Arabic writing has always been characterized as syndetic, that is, as using conjunctions to link discourse elements; and it has also been described as formulaic, that is, relying on 'fixed sets of words' (Johnstone 1990, p.218) to make semantic and syntactic links. This linguistic phenomenon, i.e. the frequent use of DMs, results in a high degree of textual cohesion in Arabic writing that contrasts significantly with the terser style of written English. Thereby, huruuf al-9atf- (such as $w a, f a$, Өитma) play a pivotal role in the realm of Arabic usage and they are looked upon as an indispensable devices for connecting and interconnecting parts of the Arabic discourse. In other words, they are a set of clues which create cohesiveness, coherence and meaning in discourse, when expressing our feelings, and ideas to others during the act of communication. Al-Batal (1990) rightly states: 'MSA seems to have a connecting constraint that requires the writer to signal continuously to the reader, through the use of connectives, the type of link that exists between different parts of the text. This gives the connectives special importance as text-building elements and renders them essential for the reader's processing of text' (ibid: 256). T'sou et al. (2003) observe that 'discourse connectives constitute a major linguistic device available for a writer to explicitly indicate the structure of a discourse'. Hence, this study has chosen 
30 written sentences, holding the Arabic DM Oumma, extracted from various MSA texts to be translated into English by bilingual Arab senior learners. However, translating these connectives is not a simple or easy task; as a matter of fact, it has been described ( Hamdan \& Fareh, 1999,p. 595) as one of the most problematic tasks that bilingual learners and translators face when endeavoring a professional performance of a text. The faulty substitution, addition or omission of a DM during a translation process of texts may lead to the decline in understanding the intended message. Crewe (1990) states that the overuse of DMs will lead to a potential communicative breakdown'(ibid: P. 317).

\section{A. The Problem}

From our earlier experience as EFL learners, and later, as teachers, seems to suggest that DMs are perhaps one of the most important components of any language course. It has been observed that Arab students of English find it difficult to translate and construct an organised and coherent text in English. Also, it has been observed that little progress is made in the efficiency of their translation. The number of students who fail translation courses covering DMs every year in comparison with other English language subjects has revealed this, which means that something has to be done to improve it and lessen the number of repeaters.

Hence, it is a sine qua non in this situation to investigate the difficulties that may account for translating Arabic sentences holding the DM Oumma by Arab university students majoring English. In other words, what concerns this study is the focus on the Arabic DM Oumma, its impact on the process of translation performed by Arab university students majoring English, in the sense that DMs facilitate grasping the intended meaning conveyed in the discourse; and vice versa is true, that is, the improper translation of a connective into a target language is likely to lead to drastic changes in meaning or to unintended meanings, in other words, DMs can explicitly indicate the function that each sentence has in a text, and they contribute to utterance interpretation effectively. It is with this research problem and its possible causes in mind; the investigators pave the way and present the research objectives in the coming section.

\section{B. Objectives of the Study}

The main purpose of this study is to identify major difficulties that Arab EFL university students and translators might face through translating sentences holding Arabic DM Oumma into English. It also aims at clarifying how this Arabic connective is interpreted and rendered into English. The implications to translating from the source language into the target language will also be highlighted. To be more specific, the study seeks answers to these questions:

1-What difficulties may translators encounter in translating Arabic texts holding the DM $\theta u m m a$ into English?

2-How do the functions of $\theta$ umma rank order in terms of difficulty?

3- What is the nearest English counterpart of each function of Arabic Oumma?

4-What implications for teaching translation from Arabic into English does this study have?

\section{The Rationale of the Study}

The rationale and need of this study emerges from two-fold justification. The first one could be attributed to the fact that, within the past twenty years or so there has been an upsurge interest in studying the theoretical status of DMs, focusing on what they are, what they mean and what uses they manifest, in spoken and written discourse, but for some reasons few studies have been conducted cross-linguistically. 'The contrastive method proves to be a useful heuristic tool capable of throwing valuable light on the characteristic features of the languages contrasted' (Firbas, 1992, P.13). Language comparison is of great interest in a theoretical as well as an applied perspective. It reveals what is general and what is language specific and is therefore important both for the understanding of language in general and for the study of the individual languages compared, (Johansson and Hofland, 1994, P. 25).

The second one, is that, most of old classical Arab grammarians were mainly interested in Al-i9raab, 'parsing' i.e. they examine each word and clause in order to work out what grammatical type each one is, in their descriptions of the DMs. That is, the textual function fulfilled by the DMs in discourse has been neglected or overlooked; while the present study has been found to focus on the functions of Arabic DM Oumma '(and)then' that may constitute difficulties to Arab learners when translate them into English. To the researchers' knowledge no studies have been conducted on 'Oumma' cross-linguistically yet. However, recently, the importance and need to investigate the textual function, i.e. the role of connectives in discourse has been noted and has attracted the attention of many discourse analysts (e.g. de Beaugrande and Dressler ,1981; Halliday and Hassan ,1976; McCarthy,1991; Schiffrin,1987; Wright, 1974; Cantarino, 1975; Al-Jubouri, 1987; Williams, 1989; Holes 1995; Stubs, 1983; Al Batal, 1990, etc.). For example, Stubs (1983) stated that 'another set of items which have not received any natural treatment within grammar are items known variously conjunctions, connectives or connectors ...'(ibid, P.72). In his book, The Syntax of Modern Arabic Prose published in (1975), Cantarino puts forward a full account and detailed analysis and description of the syntactic and semantic features of the cohesive category 'connectives in Arabic. He investigates the different functions a single connective may perform in different contexts.

To sum up, all languages make use of DMs or some such devices although the repertoire of devices and their various functions may vary from one language to another. The study will discuss how the Arabic DM Oumma is interpreted and translated into English by Arab university senior students majoring English. Generally speaking, there is no one-to-one correspondence between two languages in the field of coordination particles: most of the time their correlates in the target language have not the same pragmatic meaning, constituting translation problems to Arab learners of English and 
translators. This might be true if these languages are genetically not related, as is the case with Arabic and English. However, translation students also should know that in certain instances short function words such as wa- 'and', actually function in Arabic texts as punctuation marks would function in English texts. These connective words are therefore not always translatable because they sometimes perform strictly grammatical functions rather than adding semantic content. At the discourse or text level, the presence of appropriate connectives is an important feature of 'acceptability', according to Al-Batal, who notes that 'although 'no explicit or formal rules exist,' interconnection between sentences is essential to authentic Arabic texts' (1990,P.253). Having discussed the rationale and need for this study will brings us to our next point, which is why a translation task is employed for data elicitation procedure in this study.

\section{Why a Translation Task?}

The reason for the choice of the translation task, for eliciting the data of this study, is related to the fact that translation is one of those tasks that are most frequently used by the Arab students as EFL learners in their academic work at university. It is said that one of the most serious problems of contrastive linguistic studies is the problem of equivalence. How do we know what to compare? What is expressed in one language by, for example, Oumma - 'then' could be expressed in other languages in quite different ways. Then we do not get very far by a comparison of connnectives. Most linguists have either explicitly or implicitly made use of translation as a means of establishing cross-linguistic relationships. For instance, in his book on contrastive analysis James, C. (1980) reaches the conclusion that translation is the best basis of comparison: 'We conclude that translation equivalence, of this rather rigorously defined sort [including interpersonal and textual as well as ideational meaning] is the best available TC [tertium comparationis] for cross-linguistic analysis (ibid, P, 178). Also, in his paper on 'the translation paradigm' Levenston suggests that contrastive statements ... may be derived from either (a) a bilingual's use of himself as his own informant for both languages, or (b) close comparison of a specific text with its translation. (Levenston 1965, P. 225).

To conclude this section, when an EFL or a translator wants to understand the speaker's/writer's intended meaning, he should consider that an extra meaning is there, not because of the semantic aspects of the words themselves, but because the reader/hearer shares certain contextual knowledge with the writer/speaker of the text.

\section{E. The Significance of the Study}

It is believed that Arab university students and translators working into English as a foreign language can be evaluated by means of examining their ability to translate selected sentences holding the Arabic discourse marker Oumma, 'then' 'and then', i.e. focusing on the functions of the Arabic DM Oumma and on its English counterparts, can tell us a good deal about the students' cross-linguistic competence, and may provide important data which help in evaluating translation students and in syllabus design.

This study can also be considered significant, in that, it addresses one of the important academic issues confronting Arab students at different levels of English learning in the Arab world. In respect of this academic issue, the empirical research regarding students' performance of translating Arabic sentences containing Arabic DMs such as $\theta u m m a$, in their writing is not only scarce, but urgently needed due to the continuous faulty translation of connectives yielding a big number of mal-semantic sentences and distorted pragmatic production as referred to by several researchers (e.g. Saeed \& Fareh, 2006; Hamdan \& Fareh, 1999; Illayyan, 1990). Therefore, the primary significance of this study lies in taking a further step towards investigating and gaining a comprehensive understanding of the translating process, by providing concerned people with some new insights to facilitate the process of translating Arabic DMs, e.g. Oumma into a target language.

\section{F. Possible Causes of the Problem}

The problems that EFL students and translators often encounter in the process of translating conjunctive particles from one language into another may be ascribed to several causes. The fact that DMs do not have exact equivalents cross-linguistically may contribute to these problems. That is to say that there is no one-to-one correspondence between two languages in the field of coordination particles: most of the time their correlates in the target language have not the same pragmatic meaning, constituting translation problems to translators and learners, especially if these languages are genetically unrelated, as is the case with Arabic and English. A DM may indicate more than one logical relationship and the same logical relation may be signalled by more than one conjunctive. For instance, the Arabic DM ' $\theta$ umma' as in (1) below signals sequential function without delay, i.e. succession and immediacy are meant. Consider:شرب زيد ثم ارتوى (1) = Šariba zaidun $\theta$ umma ?irtawa=Zayd drank water then he quenched. That is to say, Zayd was thirsty and he drank water until he quenched. Also Oumma 'indicates sequence with time span, i.e. succession and non-immediacy are meant Consider: (2) zara9?a ?alfallah-u buðuura al-qamḥ-i Oumma ḥaṣada-haa = The farmer sowed the wheat seeds; and then he reaped it. i.e. the farmer first sowed the seeds of wheat in winter and then (after span of time could be four, five or six months ) he reaped it. However, the same conjunction indicates adversative function. Consider:

(3) = أعطينك ألف دينار ثم تطمع أن أزيد! ?9țaytuka ?lfa dinar Oumma taṭma9u ?n ?zeed! = I gave you a thousand dinar; but nonetheless, you covet more!

The problem becomes more aggravated when a DM in a learner's native language is best translated into a grammatical device other than a connective in the target language (e.g. adverbial conjuncts such as: e.g. causal 
conditional,e.g.then, otherwise; emphatic,e.g. moreover, furthermore; proper adversative, e.g. however, despite this; contrastive, e. g. in fact, however; dismissal, e.g. in any case, anyhow; general causal, e. g. therefore, consequently,...etc.), a non-lexical device such as punctuation marks, or even nothing (zero). As I mentioned hereinbefore, Arabic writing has great tendency to make use of DMs to link discourse elements, that is, syndetic linkage (particularly ' Oumma, wa and $f a$ as well as other DMs) whereas, in English, terseness and asyndetic linkage is commonly preferred. Sometimes in an idiomatic translation, a lot of these DMs are rendered into zero in English. Moreover, the functional polysemy that most DMs have leads to significant problems for learners and translators as well.

The faulty translation of a DM into a target language is likely to lead to drastic changes in meaning or to unintended meanings. Dickins et al. (2002, P. 87) assert that when an inappropriate DM is used, translation loss may occur on the prosodic level, for example, because the use of this DM in this particular context implies an informationally inappropriate intonation pattern. This involves that EFL learners and translators need to use DMs with utmost care and discrimination, taking into account the multiplicity of functions that DMs have in discourse. Several researchers (e.g. McCarthy, 1991; Hamdan and Fareh, 1999; Saeed \& Fareh, 2006) assert that the accuracy of translated texts should not be superficially evaluated by examining the target language text without matching it with the source language text. For example, McCarthy (1991, P. 46-47) states that discourse analysts have sought to find out whether the categories and realizations of DMs are similar or different cross-linguistically. This is considered an invitation to discourse analysts to conduct contrastive studies that aim at determining the similarities and differences between the various discourse functions of DMs for the sake of displaying the difficulties that translators and foreign language learners encounter. In this respect, Fareh (1998,) compared and contrasted the discourse functions of English 'and' and its nearest Arabic equivalent 'wa'. The results of this study revealed that the two connectives have various functions that do not often match. This mismatch, although partial, may lead to translation problems. Illayyan (1990) conducted a study to find out the difficulties that translators face in translating English texts holding transitional words into Arabic. The results of his study showed three major problems. The first problem was the unnecessary addition of an Arabic DM leading to different meaning relationships. The second problem was substituting one or more Arabic DMs or transitional words for a certain English one, which yielded in changing the intended meaning relationships between the two conjoined discourse elements. The third problem was in ignoring the explicitly stated English connective.

Hamdan and Fareh (1999) conducted a study that aimed at investigating the problems that translators confront in translating the Arabic DM wa into English. They examined six functions of wa, namely, the resumptive, the additive, the alternative, the comitative, the adversative and the circumstantial. They, also suggested conducting further contrastive studies in the area of DMs, and Karin, (2005:416) provide a very brief discussion of the functions of Arabic DMs including Oumma. Her discussion of the functions of $\theta$ umma is far from being exhaustive. She hold that $\theta u m m a$ has only one discoursal function, a sequential action coming later in time than the action in the preceding sentence or clause. In fact, Oumma has more elaborate discoursal functions than the sequential action with span of time. This succinct review of related studies shed light on the scarcity of cross-linguistic studies on DMs and the need for more indepth studies that investigate the difficulties that Arab learners of English and translators may encounter in translating from Arabic into English, especially in the area of DMs. The current study is an endeavour in this direction. Having given the problem of this study and its possible causes through a brief review of related studies, will take us to the next section which is the methodology of this study.

\section{METHODOLOGY}

\section{A. Subjects}

A total of 55 senior students of 21-22 years old were selected randomly. They constitute about $31 \%$ of total number (179) which is the population of $4^{\text {th }}$ year- $1^{\text {st }}$ semester in the academic year 2009/2010, at Al-Balqa' Applied UniversityPrincess Alia University College, Amman-Jordan. Like most of the Jordanian students, the subjects live in an exclusively Arabic-speaking community and had learned English as a foreign language at public schools prior to taking it up as their major field of study at the university. All subjects are homogeneous in terms of their linguistic, socio economic, cultural and educational background. Opportunity for naturalistic acquisition is almost all the same to all subjects. They also passed through an English placement test to measure their proficiency when they joined the department of English. The original number of the subjects was 57 students. The responses of two subjects were excluded because they did not completely translate the required translation task. When the experiment was conducted, the subjects had already studied several specialized courses of linguistics and literature including Writing I, Advanced writing, grammar, language skills, translation I \& II, syntax I \& II morphology, semantics, short story, drama, novel,...etc.

\section{B. Data Elicitation Procedure}

The instrument employed in this study for collecting the data was a translation task particularly designed for the purpose of this study. The 55 participants were asked to translate sentences from Arabic into English. Although almost all of the given sentences seem decontextualized, they were extracted from longer texts including utterances from Arabic literary textbooks, articles from magazines and newspapers, etc., (see appendix D). It is undeniable that the 
context is fundamental for comprehending the meaning of utterances and for identifying the intended functions of DMs in written discourse. However, the functions of Arabic DMs such as the $\theta u m m a$, are more often than not determined by considering the relationship holding between the two elements, sentences or clauses that a certain DM links. The task was a two-hour session, and since (Ellis \& Barkhuizen, 2005, P.27) their translation task was timed, students had no access to reference tools such as dictionaries and grammars during the test, but they were given the chance to ask questions about some words believed to be unfamiliar to them because the focus was on how they would translate the DM Oumma from Arabic into English. When analyzing the data, the researchers focused only on the translation of the targeted DM, ignoring all other types of grammatical or lexical errors, as they are beyond the scope of the study. Each student, therefore, was assigned to translate the given 40 Arabic sentences within the allotted time of a 90-minute session (the allotted time of the translation task was decided upon their translation instructors' experience in similar exams and population). Each of the five targeted functions of $\theta$ umma was represented in 8 tokens. Five well-known Arabic grammar references were examined in order to identify the discourse functions of $\theta$ umma together with the frequency of each function, these are: Al-nahw al-waafii (1963); Al-Jana Addani fii Huroof Al-Ma'anii (1992); AlKitaab.2 vols (1966); Mugni Al-Labiib ?an Kutubi-AL ?9aariib(2002); AL-mu9jam al-waafii fii adawaat al-nahw alArabi (1993). The functions of the DM Oumma in our data were found to be the only five, and they were selected on the basis of frequency and practicality. It would be a heavy burden on the subjects if each function was to be represented in more than eight tokens in the translation task, therefore, the study focuses on the five identified functions, and each of them represented in 8 tokens so totally will be forty sentences. We believe that it might be helpful, before embarking on the analysis, to provide a brief account of the five functions of $\theta u m m a$ with illustrative examples.

\section{The Functions of 'Oumma'}

The Arabic DM Oumma 'ث ('then', 'and then', 'subsequently') is one of the most commonly used connective particles in Arabic. Generally speaking, the DM Oumma is an adverb that indicates a sequential action, coming later in time than the action in the preceding sentence or clause. Syntactically, it works as coordinating conjunction that links between two elements (clauses, sentences, etc.) in order to make a compound element. It emphasizes the sequence existing between two structurally independent statements as an interval, thus, before ' $\theta$ umma', a pause or an interval in the context to be understood. In other words, it links clauses/sentences by specifying how one clause /sentence is related to another in terms of time. Oumma holds five functions as illustrated in the following.

1. Sequential Function with Span of Time

The sequential Oumma introduces a clause subordinate to the main clause by indicating time relationship between the two clauses. Semantically, this DM indicates that the two events involved in the resulting compound sentence, occurred successively, with pause of time between the two events in the sequence, and in the order indicated in the sentence. Often, the interval of time between the two events in a sequence is unspecified, consider this example:

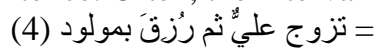

Tazawwja ?ali-un Oumma ruziqa bimawluud=Ali got married and then he got a child.

In this compound sentence, there is a logical sequence of the two events: 'getting married' and 'getting a child', the span of time between the two events is logically understood, but not specified, i.e. whether it lasted for seven, eight or nine months. That is, the length or the shortness of the span of time is determined according to the context and meaning the DM signals. But in some cases, the duration of time between the two events occurred in the sequence is specified. This is an illustrative example:

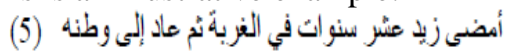

?amḍa Zayd-un 9ašru sanawaat-in fii al- gurba Oumma 9aada ?ilaa wațanih.=Zayd had spent ten years abroad (and) then he returned to his home.

This sentence means that Zayd had stayed 10 years (outside his country) continuously, (that was the first event which took 10-year duration), after that he returned back to his country, (that is the second event). So, it is obvious that there is a delay of time between the two events. Hence, on the face of it, this Oumma may translate as 'and' forming a sentence which is both grammatical and acceptable, though 'and' does not entail the implication of sequence, i.e. 'and' is unmarked for sequential temporality. So, when a semantic precision in a translation context involves a high priority, the DM Oumma, which is the only conjunction entails sequence and non-immediacy, is likely to be better rendered as 'then', 'and then', subsequently and 'after that' (after long time, after a while or after few hours) rather than 'and' or 'next' According to Baker, (1992:193) what determines the function that a DM indicates in discourse is very often governed by the context in which the DM is used. In this particular instance, context plays a significant role, as the context is a logical sequence of two events with a ten-year span of time between them.

2. Sequential with immediacy or with a short Span of Time

Syntactically, the sequential Oumma in sentence (6) works as a coordinating conjunction that links between two elements (clauses, sentences, etc.) in order to make a compound element. Semantically, it indicates sequence (in order) with no interruption between the two involved events.i.e. immediate succession of the two actions that come before and after Oumma. Consider:

استيقظتُ من النوم ثم رئَبتُ فر اشي (6)

Istayqað-tu mina al-nawm $\theta$ umma rattabtu firaashii =I woke up from sleeping (and) then I tidied my bed. 
The Oumma in sentence (6) signal a sequential and temporal relation. As a consequence of its temporal meaning, Oumma implies that the action (waking up) of the preceding sentence has been completed, thus, immediately (without much delay $=$ might be after, e.g. one, two or three minutes) introducing the new action (which is tidying the bed). Oumma may translate as $w a$ 'and' producing a grammatical and acceptable sentence, whereas, the precise function that Oumma signals, i.e. the event in the second clause 'tidying the bed' is chronologically sequent to the event occurs in the first 'waking up from sleeping', with immediacy or without much delay, is no longer implied, simply because Arabic conjunction wa 'and' does not indicate any implication of temporal sequence of the events. This interpretation of the function of $w a$ 'and' goes in line with the majority of Arab grammarians and jurisprudents (e.g. Sỉbawayh, 1966; alJuwaynī; 1996; Ibn Hisham, 2002, among others) who believe that the terms conjoined by wa 'and' enter into a participatory relationship without any implication of sequence. So, when a semantic precision is demanded as a high priority for a translation context the DM Oumma 'then' is likely to be better translated as 'then' or 'and then' rather than 'and', simply because 'then' is an adverb that indicates a sequential action coming later in time than the action in the preceding sentence or clause.

3. Resumptive Function

'Resumption' = Al-isti?naaf in Arabic can be introduced by the Arabic DM Oumma. It is very frequently used at the beginning of clauses, sentences and paragraphs but not the first. In such cases, the resumptive DM Oumma comes after a clause/sentence that had finished and, introducing a clause/sentence in order to serve the sequential function with span of time (whether it is short or long), in addition to the presumptive function where it is used to indicate speech continuity (but not topic continuity), i.e. the speaker resumes his speech, but with a new topic, presenting new information and takes the reader/hearer into quite new territory of new thought. The clause/sentence introduced by Oumma is related pragmatically in a way to the sentence mentioned before, and this pragmatic relation is being understood by both the speaker and the hearer/reader. This is an illustrative example:

(7) استرد زيد ماله. ثم عادعلي الى البيت.

Istaradda Zayd-un Maalahu. Oumma 9aada 9ali-un ilaa al-bayt-i. Zayd restored his money. Then 9ali-un (Ali) returned home.

In this sentence (7), Oumma links two sentences which are irrelevant syntactically. Each utterance is an independent meaningful sentence. The speaker/writer informs the hearer/reader two messages; each one is different from the other in its basic meaning. In the first sentence, the speaker informs the hearer that Zayd got his money back. In the second sentence, which starts with ' $\theta$ umma', the speaker resumes his discourse by introducing a new topic, that is: 9ali-un returned home. Three factors make the two utterances, before and after $\theta$ umma, are related pragmatically, that is, the two concerned utterances encoded by the same speaker, decoded by the same hearer and both utterances were said and heard in the same context. i.e. there is a pragmatic relationship between "Zayd getting his money back and 9ali-un returning home" is only understood by the speaker/writer and the hearer/reader. Of course, there is a presupposition that the two sentences are extracted from linguistic texts which are known and understood by both the speaker and hearer. Arabic tends to use extracted clauses/sentences instead of employing the whole texts for conveying such pragmatic meanings, and 'Oumma' is the tool which paves the way to indicate the speech continuity (but not topic continuity). The Arabic DMs wa 'and' and $f a$ 'next' can be used to indicate Al-isti?naaf = 'Resumption', but the sequential and temporal relation (which it could be short or long span of time) indicated by Oumma (Al-Hmouz,M.A.2001:365) is no longer implied, because $w a$, which is unmarked for sequentiality and temporality, has the additive function, and fa which stresses the connected series, indicates an immediate succession of events without any delay or pause of time between the two events. Additionally, Oumma, unlike $w a$ 'and', and $f a$ 'and', 'so' or 'next', implies the meaning of mihaad = (create the circumstances to enable something to happen). It creates new development, event or change of direction, i.e, new territory of new thought. Holes (1995:220-21) describes Oumma as 'a superordinate staging marker for the discourse as a whole'. In other words, it makes a situation in which it is very possible or more likely to enable both: the speaker to resume speech with a new topic and the hearer to understand the pragmatic relation between the two utterances, and to decode the intended meaning. Hence, translating ' $\theta$ umma' to and, so or next, the pragmatic function mihaad of 'Oumma' is no longer implied.

4. Adversative Function

Adversative'= Al-istidrakiyah in Arabic is usually expressed by the DM ' $\theta$ umma'. The adversative $\theta$ umma is used to connect two utterances (clauses, sentences) in order to make a compound element, the second of which stands in adversative relation with the preceding one. This is an illustrative example:

استيقظ زيد مبكر اثم تأخر في الوصول إلى عمله!

Istayqađ̣a Zaydun mobakkir-an Oumma ta?axara fii al-wuȘuul ?ilaa 9amalihi!=Zayd woke up early; however/but he arrived his work late!

In this example, Oumma introduces the second clause which expresses an unexpected result, i.e arriving his work late'. The most appropriate translations of adversative Oumma in a translation context where semantic precision has a high priority are likely to be but, however, or the like. The use of other devices might change or distort the logical relation between the two clauses. We use the DMs such as however, but, or the like, in the foregoing example, when you are adding a comment which is surprising or which contrasts with what has just been said. The speaker's adversative attitude in the second clause expresses negative feeling implying some sort of astonishment mixed with shock, pain or 
anger towards Zayd's being late. The two clauses of the context are linked by Oumma sequentially, i.e. the clauses of the sequence are fixed, and the tone or the quality in the speaker's voice (which shows what he is feeling or thinking when producing his utterance) determines the degree of the astonishment implied by Oumma, and also determines whether this adversative reflects the speaker's negative or positive feeling (shock, surprise, admiration, excitement, or anger, etc.). Oumma may translate as 'and' producing a sentence that is both grammatical and acceptable, but the precise function that Oumma serves, i.e. the fixed sequence of the two events and the time relationship between them, in addition to some sort of blame forwarded to Zayd, is no longer implied. In principle, however, either event might have been occurred before the other. Hence, in a translation context where semantic precision has a high priority, any translation that does not keep this logical relation held between the two parts of the sentence may be deemed faulty, though the fact that the outcome could be acceptable.

5. Consequential Function

The logical relation that this DM indicates is that of result or consequence. In Arabic, Oumma al-sababiyah' = 'the consequential Oumma', usually betokens a relationship between two clauses of a context such that the second clause describes a state or an action which occurs as a consequence of the first one. This is an illustrative example:

(9) استيظ علي مبكر ا ثم وصل المدرسة نشيطا

Istayqađ̣a 9ali-un mobakkir-an $\theta$ umma wașala al-madrasa našiiț-an=9ali woke up early; consequently, he actively arrived the school.

Sentence (9) means that 9ali actively arrived the school as a consequence of his waking up early. In other words, the second clause of this sentence, i.e. 9ali was energetic and full of life, is the result of waking up early. Hence, in a translation context where the semantic precision has a high priority, any translation that does not keep this logical relation existing between the two parts of the sentence deemed flawed, though the outcome might be acceptable. For example, when students translate Oumma '(and) then' into wa 'and', the consequential function of Oumma is no longer implied.

\section{FINDINGS AND DISCUSSION}

The above mentioned five functions are the only functions of Oumma in Arabic, and which were represented in the translation task. Each one of these functions was manifested in eight tokens which might sound to be a limitation of this study. However, each clause/sentence was excerpted from a larger text, which is not included in the appendix for the sake of time, room, economy and practicality. The full texts were not given to the subjects either, for the same reasons. The functions of ' $\theta$ umma' were identified and determined by the two researchers who are native speakers of Arabic. One of them is specialist in semantics and pragmatics of Arabic, and has long experience in teaching Arabic linguistics. The other researcher is specialist in English applied linguistics, and has long experience in teaching linguistics and translation courses. The researchers teach at both the undergraduate and graduate levels. When the researchers were in dispute over some cases, they consulted specialists in Arabic language and literature to confirm their decisions. With the help of two other colleagues whose expertise in linguistics \& translation, the researchers produced renderings of the sentences in the translation task that were deemed acceptable by all involved. In determining the acceptability of a translation, semantic accuracy as a main criterion was adopted by researchers. The researchers are fully aware of the fact that, by and large, semantic accuracy is not the only consideration that should be taken into account in launching a verdict on the acceptability of a translation. Dickins et al. (2002, P. 228-230) throughout their book 'Thinking Arabic Translation...', they highlight the notion of strategic prioritising in translation in which a creative translation strategy means 'prioritizing the cultural, formal, semantic, stylistic, and genre-related properties of the ST'. The number of functions under question in this study represents all functions of ' $\theta$ umma' in Arabic language. Each function represented in 8 tokens, so totally would be 40 sentences. As the translation task was given to 55 students, we would expect 2200 translated tokens. Table 1 shows the types of ' $\theta$ umma' and the number of tokens in the translation that represent each type. Table 2 shows the percentage and rank order of all possible correct responses for each function including the zero alternatives.

TABLE 1:

TYPES OF ' $\Theta U M M A '$ AND NUMBER OF REPRESENTATIVE TOKENS IN THE TRANSLATION TASK

Functions of $\boldsymbol{\theta u m m a}$
Sequence with span of time
Sequence with no span of time
Resumption
Adversative
Consequence
Total

$\begin{array}{ll}\text { No. of tokens } & \text { Sentence No. in Translation Task } \\ 8 & 1,2,11,12,21,22,31,32 \\ 8 & 3,4,13,14,23,24,37,38 \\ 8 & 5,6,15,16,25,26,33,34 \\ 8 & 7,8,17,18,27,28,39,40 \\ 8 & 9,10,19,20,29,30,35,36\end{array}$

Table 2 shows that the translation of Arabic ' $\theta$ umma' into English was rather difficult. The percentage of correctly translated tokens was $62 \%$. This means that more than one third, i.e. $38 \%$ of the subjects translated the tokens incorrectly. It also shows that translating the resumptive ' $\theta$ umma' was the most difficult, as only $43 \%$ of the responses were correct. The second most difficult function was when succession with non-immediacy were meant (i.e. sequence 
with span of time), followed by 'exclamation', then the 'consequence' and finally when the 'succession with immediacy' were meant (i.e. sequence with no span of time).

TABLE 2:

$\begin{array}{ll}\text { Functions of ' } \theta \text { umma' } \\ \\ 1-\quad \text { Sequence with span of time } \\ 2- & \text { Sequence with immediacy } \\ 3- & \text { Resumption } \\ 4- & \text { Adversative } \\ 5- & \text { Consequence } \\ & \text { Total }\end{array}$

NUMBER, PERCENTAGE AND RANK ORDER OF CORRECT RESPONSES

$\begin{array}{lllll}\text { No. of } & \text { Expected } & \text { No. of Correct } & \% \text { of Correct } & \text { Rank of } \\ \text { Tokens } & \text { Responses } & \text { Responses } & \text { Responses } & \text { Difficulty } \\ 8 & 440 & 221 & 50 & 2 \\ 8 & 440 & 337 & 77 & 5 \\ 8 & 440 & 191 & 43 & 1 \\ 8 & 440 & 290 & 65 & 3 \\ 8 & 440 & 311 & 71 & 4 \\ 40 & 2200 & 1313 & 62 & \end{array}$

The following will be a discussion of the results with regard to difficulties encountered in translating each function, hierarchically in terms of difficulty. What we attempt in the following discussion is to explain aspects of meaning of the Arabic DM ' $\theta$ umma' which cannot be found in the plain sense of words or structures, as explained by semantics. In other words, it is a systematic way of explaining language use in context.

\section{A. Responses to the Resumptive 'Aumma'}

Results in table 2 show that resumptive ' $\theta$ umma' was the most difficult to translate from the source language (Arabic) into a foreign language (English). The percentage of correct responses was only $43 \%$. This means that $57 \%$ of the total number of tokens representing this function was erroneously translated by Arab EFL university students. The most frequent flawed translations of resumptive ' $\theta$ umma' were and, also, next, while, and comma, whereas the possible translations included the use of and then, subsequently, suddenly, unexpectedly, or the like. Examining the erroneous translations, one might not fail to observe that the subjects seem to have not obviously identified the 'resumptive' function of Aumma in the representative source language tokens. It is also clear that the great majority of the subjects translated the resumptive function of Oumma as simultaneity, concession and addition, as can be seen from the faulty replacements of Aumma by 'and'. This is an illustrative example

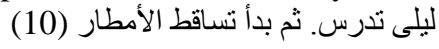

Layla tadrus-u . Oumma bada?a tasaaqot al-amțaar

Layla is studying. And then it has started raining.

The DM Oumma was erroneously rendered by $36 \%$ of the subjects as 'and', $11 \%$ as 'also' and $10 \%$ as comma, zero (nothing) respectively. The faulty responses indicate that the subjects failed to recognize the logical relationship holding between the two sentences. The faulty use of and or also instead of the possible DM 'then' or 'and then' changed the intended meaning of the target language text. Moreover, the wrong use of the comma leads to the formation of a run-on sentence, a feature that is unacceptable in formal written English. Since we do not use a comma with the conjunctive adverb 'then' Aumma, a semicolon or full stop followed by then or and then, etc., would have been more appropriate than a comma alone. Anyway, it is acceptable in English as well as in Arabic to use a semicolon or full stop immediately at the end of the first sentence, followed by the DM Oumma (then, and then, subsequently, etc.) to introduce the second sentence to indicate speech continuity. It bears repeating here that one should consider that an extra meaning is there, not because of the semantic aspects of the words themselves, but because the reader/hearer shares certain contextual knowledge with the writer/speaker of the text.

\section{B. Responses to the Sequential 'Oumma' with Span of Time}

The results in table 2 show that this function was found to be the second most difficult one. Only $50 \%$ of the responses were correct. The possible translations of this type of Aumma include: then, and then, after that (after long time, after a while or after few hours) subsequently, etc. Findings showed that about $30 \%$ of the subjects mistakenly translated Oumma into English 'and' instead of 'then', 'and then', 'subsequently'...etc. The DM 'and' does not entail the idea of temporal sequence, i.e. 'and' is unmarked for temporality, therefore, when translating ' $\theta$ umma' into 'and', the sequential- temporal function of ' $\theta$ umma' is no longer implied. The analysis of the data also revealed that $17 \%$ of the subjects inappropriately replaced 'then' or 'and then' by 'next' which indicates two events occurred consecutively and without delay. In the remaining portion of the flawed responses, the subjects used comma to conjoin the two clauses which gives the formation of a run-on sentence, a feature leads to malformed structure in formal English, though in Arabic is allowed to employ 'Oumma' ('then' or 'and then') without comma or semicolon before or after the DM ' $\theta$ umma'. This is an illustrative example.

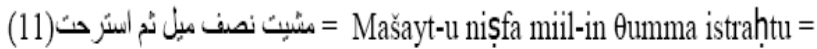

I walked a half mile; and then I rested.

This sentence means that first, 'I walked half a mile', then, and then, after that (after long time, after a while or after few hours) subsequently, etc., 'I lied down and took some rest', i.e. The DM 'Oumma' indicated the sequence of the two events with significant delay between the two clauses. The translation 'I walked a half mile and rested' does not necessarily impose any absolute ordering of the events of walking and resting although its most normal interpretation would be that the writer walked half a mile first. In principle, however, either action might have been occurred before 
the other. This shows that 'and' is not the most precise semantic translation equivalent of $\theta u m m a$ in such a context. The flawed translations suggest that the subjects were not able to determine the intended function of Oumma in the source language tokens.

\section{Responses to the Adversative 'Oumma'}

Table 2 showed that the third most difficult function to translate was the adversative Oumma. The correct responses constituted $65 \%$ of the total answers. The possible translation of adversative function includes the use of nevertheless, but, however, on the contrary, despite this, but nonetheless, etc. The analysis of the data indicated that $31 \%$ of the subjects inappropriately translated ' $\theta$ umma' into 'and'. Furthermore, $4 \%$ of the subjects wrongly used comma, semicolon instead of 'Oumma'. Anyhow, all the faulty responses and, semicolon, comma, employed by translation students as a replacement of Oumma do not precisely capture the intended meaning of this Arabic DM. Here is an illustrative example:

تر عى الأم أبناءها حتى يكبرو ا ثم لا تلقى منهم معاملة حسنة! (12)

tar9aa al?ummu abnaa?ah-aa ḥatta yakbaruu $\theta$ umma laa talqaa minh-um mo9aamala ḥasana! = The mother takes care of her children until they grow up; nevertheless, she does not receive the good treatment from them.

\section{Responses to the Consequential 'Oumma'}

Translations such as: 'The mother takes care of her children until they grow up; and/semicolon / comma she does not receive the good treatment from them', are unacceptable because there is an obvious change in the intended relationship holding between the two clauses of the source language token ( the adversative relationship). The resultative ' $\theta$ umma' usually indicates a relationship between two clauses of a context such that the second clause describes a state or an action which occurs as a result of the first one. Numbers in table 2 indicated that the fourth difficult function to translate was the consequential ' $\theta$ umma'. The percentage of the correct responses was $71 \%$. The possible translations of the consequential 'Oumma' include therefore, thus, hence, consequently, and so, so that, so. The relatively high percentage of correct answers may be attributed to the fact that the consequential ' $\theta$ umma' in Arabic can easily be replaced by liðaalika = 'so', which commonly translates into English as 'so' introduces the clause that provides the result or consequence of the first one. The inappropriate translations of consequential ' $\theta$ umma' include the use of so as, with a percentage of $21 \%$. However, so as is used to introduce the reason for doing the thing that you have just mentioned. In the remaining portion ( $8 \%$ ) of the faulty responses, the subjects used as...so, as, because. This type of $\theta u m m a$ is best rendered as so, therefore, thus, hence, consequently. The faulty translations show that some of the subjects confused between functions of the Arabic DM $f a$ which is called' $f a$ al-sababiyya (causal $f a$ ) (=so as, because, since or as) and the resultative Oumma (=so, therefore, thus, hence, consequently. The former one, i.e. the causal fa introduces the second clause that provides the cause or the reason of the event stated in the first clause of the compound element. Consider the following example (13) laa tabki fa?inna al-bukaa?a da9f-un.=Don’t cry because crying is weakness.

In sentence (13), the clause introduced by $f a$ 'because' provides the cause or the reason of the action/event stated in the first clause, which is 'don't cry'. Whereas, the latter, i.e. Oumma al-Natiija = consequential/resultative $\theta u m m a$, usually indicates a relationship between two clauses of a context such that the second clause describes a state or an action occurs as a consequence/result of the cause/reason which occurs in the first clause; Consider the following example:

= الذي حضر ثم قام الأو لاد المعلمُ (14) =

?al-laðii ḥaḍara Oumma qaama al-awlad-u al-mu9alim = The teacher came; so the boys stood up.

In sentence (14) which consists of two clauses linked by Oumma, means that the boys stood up as a respect for their teacher who came to their classroom. In other words, the cause or reason that the boys stood up was the teacher's coming. Therefore, the faulty translations ( so as, because, just as...so, as...so, that ) show that the use of a DM that does not signal a consequential relationship between the two clauses joined by Arabic Oumma would yield an unacceptable translation because of the change in the intended meaning of the source language token.

\section{E. Responses to the Sequential Oumma with Immediacy}

Findings in table 2 show that the sequential function with no pause or delay was the easiest to translate. The analysis of the data showed that $77 \%$ of the responses were correct. The possible translations of the sequential ' $\theta$ umma' with no span of time include and ...immediately, soon, then, and then, at once, in a second, followed by. The analysis of the data revealed that $19 \%$ of the subjects inappropriately used 'and' instead of 'then'. Furthermore, 4\% of the subjects mistakenly used 'so' or 'and so'. It might be worth mentioning at this point that ' $\theta$ umma' does not usually translate as 'and', because 'and' is unmarked for temporal relationship and does not necessarily indicate sequence with order. In this kind of the sequential function, Arabic 'Oumma' is used to mean that two events occurred consecutively and without delay; whereas 'and' does not necessarily imply the successive occurrence of events, i.e. happening one after the other without unusual interruption. This is an illustrative example:

= دخل محمدٌ الغرفة ثم أغلق الباب (15) =

Daxala Mohammed-un algurfa-ta $\theta$ umma ?ağlaqa al-baab.= Mohammed entered the room; then closed the door.

Sentence (15) means that Mohammed entered the room first and he closed the door immediately without any significant delay. The translation 'Mohammed entered the room and closed the door' does not necessarily impose any 
absolute ordering of the events of 'entering the room and closing the door', although its most normal interpretation would be that the writer entered the room first. In principle, however, either action might have been before the other. In other words, 'and' indicates grouping, but doesn't specify order or timing. Therefore, translating ' $\theta$ umma' into English 'and' does not precisely capture the intended meaning of ' $\theta$ umma' in the source language text. An exception might be there is that and implies sequence only when combination is untenable. This entails that 'and' is not the precise semantic translation equivalent of ' $\theta$ umma' in such a context. The faulty translations suggest that some of the subjects failed to determine the intended function of ' $\theta$ umma' in the source language tokens.

\section{BY WAY OF CONCLUSION}

A careful look at the results warrants these observations:

(1) EFL Students do not usually have much difficulty in understanding certain rules or classifications, but when they need to apply them they sometimes fail to do so. As Goldman and Murray (1992:505) rightly state 'ESL students frequently are very good in reciting the prescriptive rules of usage for various [conjunctions], but to master the appropriate use of conjunctions is 'extremely difficult'. Geva also (1992:735) highlighted that 'adult L2 learners may demonstrate familiarity with the meaning of conjunctions, yet fail to utilize them in extended discourse'.

(2) The translation of the Arabic DM 'Oumma' was, on the whole, not easy. The average percentage of the correct responses was $62 \%$, which means that more than $1 / 3(38 \%)$ of the total responses was incorrect. However, it was observed that the resumptive and sequential functions of ' $\theta$ umma' were more difficult to translate than the other three types.

(3) The use of ' then' in translating the resumptive 'Oumma' was more frequent than its synonyms; and the use of 'and then' in translating the sequential ' $\theta$ umma' with or without pause, was more frequent than its synonyms. Similarly, the use of 'so' in translating the consequential ' $\theta$ umma' was much more frequent than its synonyms.

(4) Very often, the subjects did not distinguish between the causal and the resultative functions of the Arabic DMs $f a$ and 'Oumma' respectively. This might account for the subjects' use of as, because, instead of 'so' in translating the consequential 'Oumma'.

(5) The use of punctuation marks, the semicolon in particular, to connect two related sentences was very seldom. However, the comma was inappropriately used to link two clauses where the result was often a run-on sentence, a feature which is not acceptable in appropriate English. Also, the sequential ' $\theta$ umma' in both cases (with or without span of time) was frequently rendered as 'and', with the result of changing the logical relationship holding between the two sentences.

(6) The improper translation of functions of the Arabic DM $\theta u m m a$ is prominent among Arab EFL students even at advanced stages of their learning. This indicates their insufficient knowledge of what, when and how to translate textual functions of Arabic DMs into English.

\section{IMPLICATIONS \& FUTURE DIRECTIONS}

The results of the study and the foregoing observations inspire and motivate the formulation of the following implications to EFL learners, translators and to the process of teaching translation:

(1) Generally speaking, DMs are items that are notoriously difficult to describe regarding all linguistic levels involved and it is not even clear whether they constitute a class. The main problem in the description of DMs, however, is taken to be their functional polysemy. DMs contribute essentially to the interpretation process. From this theoretical perspective, DMs are considered signals the writer/speaker uses to guide cooperatively his reader/hearer's interpretative process. Hence translators and translation students need not to beware, but be aware of the multiplicity of functions that each DM may signal in discourse.

(2) In general, there is no one-to-one correspondence between two languages in the field of DMs: most of the time their correlates in the target language have not the same pragmatic meaning, constituting a usual pitfall in translation. This may be especially true if these languages are genetically unrelated, as is the case with Arabic and English. Consequently, DMs should constitute a major component of a larger whole in the syllabus of translation courses. EFL Learners should be trained to recognize and identify the role that DMs play in entailing/indicating logical relations between clauses and sentences in discourse.

(3) Since the findings of this study shed light on the difficulties that EFL learners encounter in translating the DM ' $\theta$ umma', it might be helpful, in teaching writing courses, to focus on the use of intra/inter-sentential relations as well as the devices used to create these connections.

(4) Since determining the function that a DM signals in discourse is usually governed by the context in which the DM is used; in a translation context where semantic precision has a high priority, EFL learners and translators should consider that an extra meaning is there, not because of the semantic aspects of the words themselves, but because the reader/hearer shares certain contextual knowledge with the writer/speaker of the text.

(5) The results of this study back up the recommendations suggested by McCarthy (1991), Hamdan and Fareh (1999), Saeed and Fareh (2006), that the accuracy of translated texts should not be superficially evaluated by examining the target language text without matching it with the source language text. For example, McCarthy (1991: rightly states 
that 'discourse analysts have sought to find out whether the categories and realizations of DMs are similar or different cross-linguistically (ibid, 46-47). In other words, when EFL learner or a translator describes a relationship signalled by certain DM superficially, he means that it indicates only the explicit aspect of that relationship, and not those implicit (implied) aspects which require more effort to deal with or understand, especially where semantic precision has a high priority. In this respect, there is nothing wrong in the sentence 'I gave you a thousand dinar and you covet more'. But when matched with the source language text, the use of 'but' or 'but nonetheless' instead of 'and' would be a more appropriate translation equivalent of the source language text in which adversative Oumma is used. This does not mean that the connective 'and' cannot be used in an adversative sense in certain contexts.

(6) EFL undergraduates and translators working into English as a foreign language can be evaluated by means of examining their ability to translate selected sentences, holding DMs, extracted from several types of literary texts of the source language. Meanwhile, focusing on the pragmatic functions of these DMs and on their English equivalents, can tell us a good deal about the students' cross-linguistic competence, and may provide important data which help in evaluating translation students and in syllabus design. Equipped with this methodology, the educator or assessor may construct instruments to profile subjects so that they can be placed in appropriate instructional grades, as well as design appropriate syllabus objectives.

(7) The poor performance of EFL Arab undergraduates in translating textual functions of $\theta u m m a$, indicates the need for instruction especially designed to clarify the implicatures stand beyond the literal sense of what explicitly stated by a DM in certain context. Therefore, we end by recommending further cross-linguistic work in this area, including other Arabic DMs such as fa, wa, innama, lakinna, bal bainama, lakin, etc., and their English counterparts which can be an interesting and fruitful topic to the real needs of EFL learners, translators and translator educators in a post-colonial world.

APPENDIX A: MSA VOWELS USED IN THE EXAMPLES

\begin{tabular}{|l|l|l|}
\hline SR & MSA Vowel & Description and an example From Arabic and its meaning in English \\
\hline $1-$ & i & Short high front unrounded eg. Sit = English : six \\
\hline $2-$ & ii & Long high front unrounded e.g. Haziin = English : Sad \\
\hline $3-$ & u & back high rounded short e.g. sum = English : deaf \\
\hline $4-$ & uu & High back rounded long e.g. kub=English $:$ cup \\
\hline $5-$ & a & low central unrounded Short e.g.mal =English: got bored \\
\hline $6-$ & aa & Front low unrounded long e.g.maal=English $:$ money \\
\hline
\end{tabular}

APPENDIX B: MSA DIPHTHONGS USED IN THE STUDY

\begin{tabular}{|l|l|l|l|}
\hline SR & MSA diphthong & Example from MSA & English Meaning \\
\hline $1-$ & ay & As in 'bayt' & 'house' \\
\hline $2-$ & aw & As in 'yawm & 'day' \\
\hline
\end{tabular}

APPENDIX C: MSA CONSONANTS USED IN THE EXAMPLES OF THE STUDY

\begin{tabular}{|c|c|c|c|}
\hline S.N. & Arabic consonants & English Equivalents & Description of the sounds \\
\hline $1-$ & ! أ & $?$ & glottal stop \\
\hline $2-$ & ب & $\mathrm{b}$ & a voiced bilabial stop \\
\hline $3-$ & $ت$ & $\mathrm{t}$ & a vl non-emphatic denti-alveolar fricative \\
\hline 4- & ث & $\theta$ & a vl non-emphatic denti-alveolar fricative \\
\hline $5-$ & ج & $\mathrm{j}$ & a vd palato-alveolar fricative \\
\hline $6-$ & $\tau$ & h & a vl pharyngeal fricative \\
\hline $7-$ & $\dot{\tau}$ & $\mathbf{x}$ & a voicelesss uvular fricative \\
\hline $8-$ & د & $\mathrm{d}$ & a voiced non-emphatic denti alveolar stop \\
\hline 9- & $\dot{j}$ & д & A voiced interdental fricative \\
\hline $10-$ & J & $\mathrm{r}$ & A voiced alveolar flap \\
\hline $11-$ & j & $\mathrm{Z}$ & A voiced palato-alveolar fricative \\
\hline $12-$ & س & $\mathbf{s}$ & A vl non-emphatic denti-alveolar fricative \\
\hline 13- & ش & $\check{\mathbf{s}}$ & A voiceless palato-alveolar fricative \\
\hline 14- & ص & Ș & A voiceless emphatic denti-alveolar fricative \\
\hline $15-$ & ض & $\underline{d}$ & A voiced emphatic denti-alveolar plosive \\
\hline 16- & $b$ & $\mathrm{t}$ & A voiceless emphatic denti-alveolar plosive \\
\hline $17-$ & ظ & đ/ z & A voiced emphatic denti-alveolar fricative \\
\hline $18-$ & $\varepsilon$ & 9 & A voiced pharyngeal fricative \\
\hline 19- & $\dot{\varepsilon}$ & $\dot{\mathrm{g}}$ & A voiced uvular fricative \\
\hline 20 & ف & $\mathrm{f}$ & A voiceless labiodental fricative \\
\hline $21-$ & ق & $\mathrm{q}$ & Voiceless uvular plosive \\
\hline $22-$ & s & $\mathrm{k}$ & A voiceless velar plosive \\
\hline $23-$ & J & $\mathrm{L}$ & a voiced alveolar lateral \\
\hline $24-$ & 5 & $\mathrm{~m}$ & a voiced bilabial nasal \\
\hline
\end{tabular}




\begin{tabular}{|l|c|c|l|}
\hline $25-$ & $\dot{u}$ & $\mathrm{n}$ & A voiced alveolar nasal \\
\hline $26-$ & 0 & $\mathrm{~h}$ & glottal fricative \\
\hline $27-$ & $و$ & $\mathrm{w}$ & Labial-velar semi-vowel \\
\hline $28-$ & $\mathrm{s}, \mathrm{y}$ & y & A palatal semi-vowel \\
\hline
\end{tabular}

ApPENDIX D: Translation Task: (a QUeStionnaire of 40 ARABIC SENTENCES)

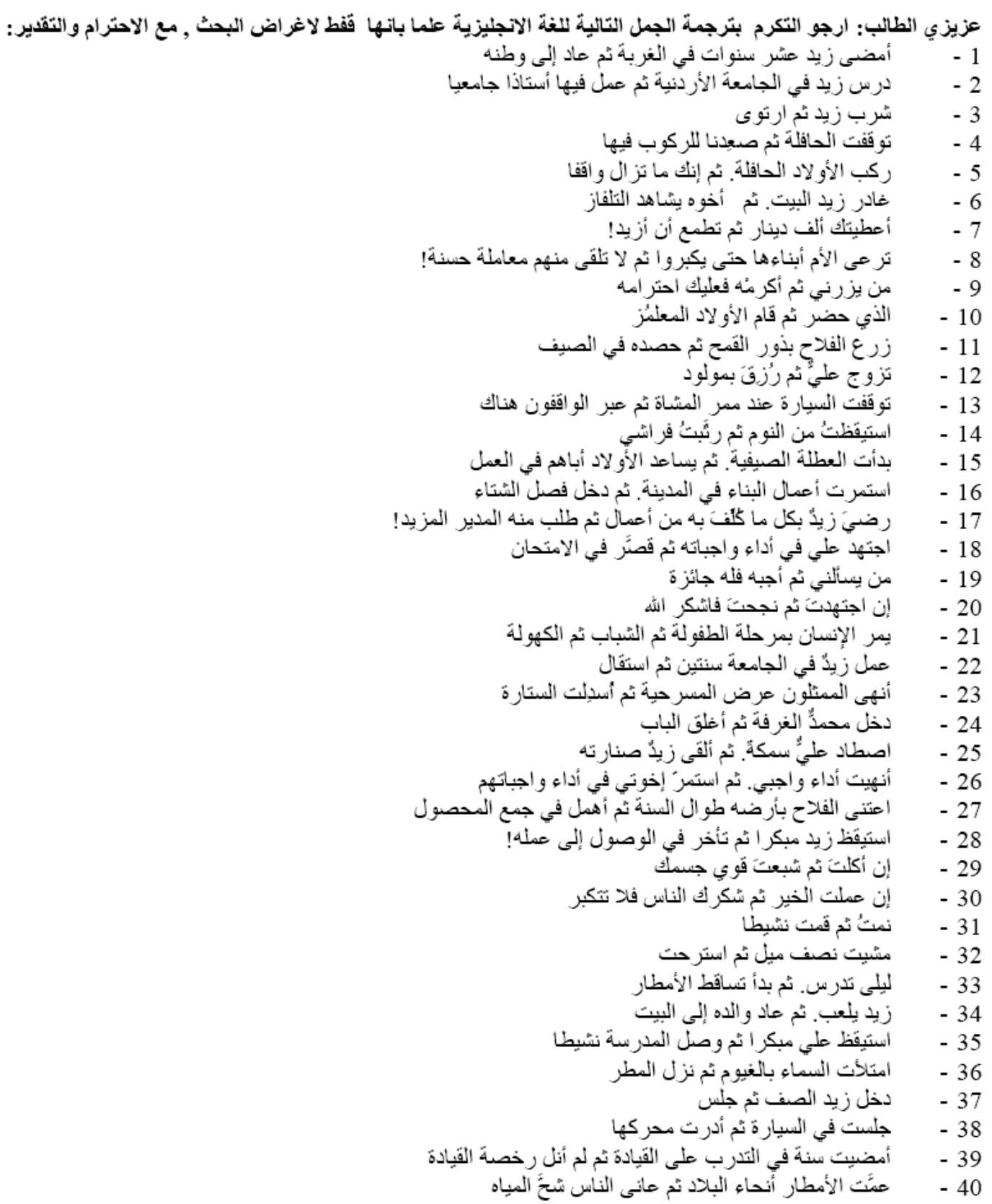

\section{REFERENCES}

[1] Al-Batal, M. (1990). Connectives as cohesive elements in a modern expository Arabic text. In Perspectives on Arabic Linguistics II, ed. Mushira Eid and John McCarthy. Amsterdam/ Philadelphia: John Benjamins.

[2] Al-Ḥamad. A., \&Al-Zu9bi,Y.(1993). AL-mu9jam al-waafii fii adawaat al-nahw al-Arabi. Al amal-Irbid-Jordan.

[3] Al- Hmouz,M.A.(2001). Al-Rasheeed fi al-nahw al-Arabi . Dar Alsafa' . Amman: Jordan.

[4] Al-Jubouri, A. J. R. (1987). Computer-ided categorisation and quantifaication of connective in English and Arabic, University of Aston in Birmingham (U.K.).

[5] Arberry, A.J. (1998). The Koran. Oxford: Oxford University Press.

[6] Cantarino, Vicente. (1974, 1975, 1976). The Syntax of modern Arabic prose. 3 vols. Bloomington Indiana University Press.

[7] Crewe, W.J. (1990). The illogic of logical connectives. ELT Journal, 44 (4), 316-325. 
[8] De Beaugrande, R. and Dressler, W. (1981). Introduction to text linguistics. London: Longman.

[9] Dickins, J., Hervey, S. and Higgins, I. (2002). Thinking Arabic translation: a course in translation method: Arabic into English. London: Routledge.

[10] Ellis \& Barkhuizen, G. (2005). Analyzing learner language. Oxford University Press.

[11] Firbas, Jan. (1992). Functional sentence perspective in written and spoken communication. Cambridge: Cambridge University Press.

[12] Geva, E., (1992). The role of conjunctions in L2 Text comprehension. TESOL Quarterly 26 (4), 731-747.

[13] Goldman, S. R., \& Murray J. D., (1992). Knowledge of connectors as cohesion devices in text: a comparative study of nativeEnglish and English-as-a-second language speakers. Journal of Educational Psychology 84 (4), 504-519.

[14] Halliday, M.A.K. and Hasan, R. (1976). Cohesion in English. London: Longman

[15] Hamdan, J. and Fareh, S. (1999). The translation of Arabic Wa into English: Some problems and implications. Dirasat: Human and Social Sciences 26, 2. 590-603.

[16] Hasan, 9abbaas. (1963). Al-Nahw al-Waafii.Vol. II. Cairo: Daar al-Ma9aarif bi-Mișr,

[17] Holes, C. (1995). Modern Arabic: structures, functions and varieties. London: Longman

[18] Ibn-Hishaam, Jamal Al-Deen Ibn-Hishaam Anșaari (died in 761h) (2002). Muġni Al-Labiib? an Kutubi- AL ?9aariib. (annotated and edited by A.L. Al- Khatib). Kuwait: Al-Turaath Al-Arabi.

[19] Illayyan, M. (1990). Transitional words and the Arab translator.MA Thesis, YarmoukUniversity, Irbid-Jordan.

[20] James, Carl. (1980). Contrastive analysis. London: Longman.

[21] Johnstone, Barbara. (1990). "Orality" and discourse structure in Modern Standard Arabic. In perspectives on Arabic linguistics I, ed. Mushira Eid. Amsterdam/ Philadelphia: John Benjamins, 215-233.

[22] Johansson, Stig and Knut Hofland. (1994). Towards an English-Norwegian parallel corpus. In U. Fries, G. Tottie, and P. Schneider (eds.), Creating and using English language corpora, 25-37. Amsterdam and Atlanta, GA: Rodopi.

[23] Kammensj, H. (1993).Connectives in MSA and/or ESA: suggestion for research Gothenburg: University of Gothenburg Department of Oriental Languages.

[24] Karin C.R. (2005). A Reference grammar of modern standard Arabic. Cambridge University Press.UK.

[25] McCarthy, M. (1991). Discourse analysis for language teachers. Cambridge: Cambridge University Press.

[26] Qubbawah, F. \& Fadhil, M. N. (1992). Al-Jana Addani fii Huroof Al-Ma'anii. Dar Alkutub Al ilmiyah. Beirut-Lebanon.

[27] Saeed A.T. \& Fareh, S (2006). Difficulties encountered by bilingual Arab learners in translating Arabic 'fa' into English. The International Journal of Bilingual Education and Bilingualism, Vol. 9, No.1.19-31.

[28] Schiffrin, D. (1987a). Discourse markers. Cambridge: Cambridge University Press

[29] Sibawayh, 9amr Ibn 9uthmaan (d.177 h.) (1966). Al-Kitaab: Kitaab Sibawayh.2 vols. Edited by Abdulsalaam M. Haaruun. Cairo: Daar al- 9ilm.

[30] Stubs, M. (1983). Discourse analysis: the sociolinguistic analysis of natural language. Chicago: University of Chicago Press.

[31] T'sou, B.K., Lin, H.L., Lai, T.B.Y. and Chan, S.W.K. (2003). Human judgment as a basis Evaluation of discourse-connectivebased full-text abstraction in Chinese. International Journal of Computational Linguistics and Chinese Language Processing 3 , 1 .

[32] Williams, M. P. (1989). A comparison of the textual structures of Arabic and English written texts: A Study in the comparative orality of Arabic. University of Leeds, (U.K.).

Yousef Tahaineh is an Assistant Professor of Applied Linguistics at Al-Balqa' Applied University-Amman, Jordan. His interests include English Applied Linguistics, matters central to L2 learners' syntactic, semantic, lexical and phonological errors. He currently works on Discourse markers-functions, conventional semantic and pragmatic meanings cross-linguistically.

Raid Tafish is an Assistant professor in semantics and pragmatics of Arabic. Al-Balqa' Applied University-Amman, Jordan. His interests include Arabic Applied Linguistics, semantics \& pragmatics of classical and Modern Standard Arabic. He currently works on Discourse markers-functions, conventional semantic and pragmatic meanings in Arabic. 